\title{
Production of Lactic Acid from Seaweed Hydrolysates via Lactic Acid Bacteria Fermentation
}

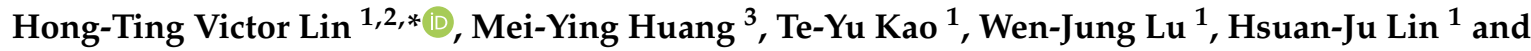 \\ Chorng-Liang Pan ${ }^{1, *}$
}

1 Department of Food Science, National Taiwan Ocean University, No. 2, Pei-Ning Road, Keelung 202, Taiwan; teyukau@gmail.com (T.-Y.K.); miss350100@gmail.com (W.-J.L.); angel810801@gmail.com (H.-J.L.)

2 Center of Excellence for the Oceans, National Taiwan Ocean University, No. 2, Pei-Ning Road, Keelung 202, Taiwan

3 Division of Aquaculture, Fisheries Research Institute, Council of Agriculture, No. 199, Hou-Ih Road, Keelung 202, Taiwan; myhuang@mail.tfrin.gov.tw

* Correspondence: HL358@ntou.edu.tw (H.-T.V.L.); b0037@mail.ntou.edu.tw (C.-L.P.); Tel.: +886-2-24622192 (ext. 5121) (H.-T.V.L.); +886-2-24622192 (ext. 5116) (C.-L.P.); Fax: +886-2-24634203 (H.-T.V.L.); Fax: +886-2-24634203 (C.-L.P.)

Received: 22 February 2020; Accepted: 22 March 2020; Published: 24 March 2020 updates

\begin{abstract}
Biodegradable polylactic acid material is manufactured from lactic acid, mainly produced by microbial fermentation. The high production cost of lactic acid still remains the major limitation for its application, indicating that the cost of carbon sources for the production of lactic acid has to be minimized. In addition, a lack of source availability of food crop and lignocellulosic biomass has encouraged researchers and industries to explore new feedstocks for microbial lactic acid fermentation. Seaweeds have attracted considerable attention as a carbon source for microbial fermentation owing to their non-terrestrial origin, fast growth, and photoautotrophic nature. The proximate compositions study of red, brown, and green seaweeds indicated that Gracilaria sp. has the highest carbohydrate content. The conditions were optimized for the saccharification of the seaweeds, and the results indicated that Gracilaria sp. yielded the highest reducing sugar content. Optimal lactic acid fermentation parameters, such as cell inoculum, agitation, and temperature, were determined to be $6 \%(v / v), 0 \mathrm{rpm}$, and $30^{\circ} \mathrm{C}$, respectively. Gracilaria sp. hydrolysates fermented by lactic acid bacteria at optimal conditions yielded a final lactic acid concentration of $19.32 \mathrm{~g} / \mathrm{L}$.
\end{abstract}

Keywords: fermentation; lactic acid; macroalgae; Gracilaria sp.; Sargassum siliquosum; Ulva lactuca

\section{Introduction}

Lactic acid, a colorless and odorless monocarboxylic acid [1], has received considerable attention owing to its various applications in food and non-food industries [2]. For example, there has been an increasing demand of lactic acid in the manufacturing of biodegradable polylactic acid materials used as an alternative to petroleum-derived plastics [3]. It was estimated that the worldwide demand for lactic acid would reach 1,000,000 metric tons by the year 2020 [4].

Lactic acid can be produced by either chemical synthesis or microbial fermentation. Two optical isomers of lactic acid, L(+)- and D(-)-lactic acid, are produced during its chemical synthesis; of these, $\mathrm{D}(-)$-lactic acid is considered to be the main entity involved in human acidosis [5]. As a result, a variety of microbial strains, such as the fungus Rhizopus [6-8], yeast Pichia stipitis [9], and lactic acid bacteria $[10,11]$, have been used in microbial fermentation for lactic acid production. Fermentation parameters along with the medium compositions for the production of pure $\mathrm{L}(+)$-lactic acid of microbial origin have been thoroughly optimized [7,12-14]. Moreover, engineered microbial strains have been 
reported for the efficacious production of lactic acid. Liaud et al. [4] indicated that Aspergillus brasiliensis could produce more lactic acid as a result of the insertion of recombinant $i d h A$ genes obtained from R. oryzae. Metabolically engineered Saccharomyces cerevisiae and A. oryzae could produce lactic acid more efficiently if a bovine L-lactate dehydrogenase gene $(L D H)$ was integrated into their genome $[15,16]$. Candida sonorensis expressing a heterologous lactate dehydrogenase from Lactobacillus helveticus could produce lactic acid by xylose fermentation [17].

Although extensive studies have been reported to efficiently improve lactic acid production by microbial fermentation, the high production cost of lactic acid still remains the major limitation for its application, indicating that the cost of carbon sources for the production of lactic acid has to be minimized for industrial application [18]. Many studies on lactic acid production by the fermentation of starchy materials, such as corn starch [19-21], rice starch [22], potato starch [23,24], and sweet sorghum juice [25], have been reported. However, scientists have been searching for a relatively cheap carbon source for the microbial fermentation of lactic acid. Renewable lignocellulosic biomass materials have been reported to be low-cost carbon sources and as feedstock for lactic acid fermentation, including waste sugarcane [18], corn stover [26], apple pomace [27], wheat straw [28,29], and wood waste [30]. However, producing lactic acid from lignocelluloses has limitations, given the inherent inefficiency of extracting lignin, a cell wall polymer of aromatic subunits and also a negative substance in the biochemical process during fermentation.

Marine algae are now attracting considerable attention as possible complementary/alternative lignocellulosic substrates because of several advantages. First, marine algae have a short generation cycle and can be easily cultivated in various aquatic environments. Second, they are not considered as a primary food crop and do not contain lignin, which makes saccharification more feasible. Third, they are rich in carbohydrates. Utilization of lignocellulosic biomass for biofuel or lactic acid production might incur environmental consequences and economic impacts associated with land use and water consumption [31]; clearing new land for lignocellulosic biomass production might have limitations, since greater needs for major food crops will certainly come with a growing world population. A lack of source availability of food crop and lignocellulosic biomass has encouraged researchers and industries to explore new feedstocks for microbial fermentation, such as seaweeds due to their favorable rapid growth rate and cultivation in the aquatic environment [32]. Jung et al. [33] indicated that the amount of some seaweeds is approximately four and six orders of magnitude greater than the lignocellulosic biomass, such as corn stover and switchgrass. In addition, seaweeds exhibited a higher photosynthetic efficiency than that of terrestrial biomass [34,35], leading to their high crop yields and carbon fixation. On the other side, lignocellulosic biomass is dominant in cellulose and hemicellulose, which break down into mostly glucose and xylose. However, seaweeds have versatile polysaccharides, such as fucoidan and laminaran in brown seaweeds, agar and carrageenan in red seaweeds, and ulvan and glucuronan in green seaweeds, and it is worth evaluating their potentials for lactic acid fermentation [36].

To date, marine algae have been used in the production of bio-based chemicals $[37,38]$ and biofuels $[39,40]$, which is an indication of their great potential as carbon sources for lactic acid fermentation. In this study, we used lactic acid bacteria for the fermentation of the marine algae Gracilaria sp., Sargassum siliquosum, and Ulva lactuca for lactic acid production.

\section{Results and Discussion}

\subsection{Proximate Compositions of Dried Seaweeds Gracilaria sp., S. siliquosum, and U. lactuca}

The proximate compositions of the three dried marine algae Gracilaria sp., S. siliquosum, and U. lactuca are presented in Table 1. Gracilaria sp. comprised 7.54\% $\pm 0.42 \%$ moisture, $11.86 \% \pm 0.16 \%$ crude protein, $1.42 \% \pm 0.05 \%$ crude fat, $14.49 \% \pm 1.23 \%$ ash, and $64.69 \% \pm 0.32 \%$ carbohydrate. S. siliquosum comprised $13.83 \% \pm 0.61 \%$ moisture, $9.61 \% \pm 0.35 \%$ crude protein, $0.56 \% \pm 0.05 \%$ crude fat, $12.08 \% \pm 0.85 \%$ ash, and $63.92 \% \pm 0.33 \%$ carbohydrate. U. lactuca comprised $11.29 \% \pm 0.21 \%$ moisture, $21.54 \% \pm 0.06 \%$ crude protein, $0.51 \% \pm 0.02 \%$ crude fat, $22.75 \% \pm 0.37 \%$ ash, and $43.91 \% \pm 0.42 \%$ carbohydrate. There have 
been reports that the red alga Pterocladiella capillacea, green alga U. lactuca, and brown alga Sargassum fulvellum have carbohydrate contents of $80 \%$ [39], 61\% [41], and 44.5\% [42], respectively. Wang, et al. [43] used lignocellulosic biomass soybean straw for lactic acid fermentation, and showed that soybean straw comprised $53.35 \%$ carbohydrate (cellulose 30.92\% + hemicellulose $22.43 \%$ ), $17.64 \%$ lignin, and $9.12 \%$ proteins. These results suggested that marine algae are rich in carbohydrates, making them promising candidates for biomass for lactic acid fermentation.

Table 1. Proximate composition (\%) of driedred seaweed Gracilaria sp., brown seaweed S. siliquosum, and green seaweed U. lactuca.

\begin{tabular}{cccc}
\hline Components & Gracilaria sp. (\%) & S. siliquosum (\%) & U. lactuca (\%) \\
\hline Moisture & $7.54 \pm 0.42^{\mathrm{b}}$ & $13.83 \pm 0.61$ & $11.29 \pm 0.21$ \\
Carbohydrate $^{\mathrm{a}}$ & $64.69 \pm 0.32$ & $63.92 \pm 0.33$ & $43.91 \pm 0.42$ \\
Crude Protein & $11.86 \pm 0.16$ & $9.61 \pm 0.35$ & $21.54 \pm 0.06$ \\
Crude fat & $1.42 \pm 0.05$ & $0.56 \pm 0.05$ & $0.51 \pm 0.02$ \\
Ash & $14.49 \pm 1.23$ & $12.08 \pm 0.85$ & $22.75 \pm 0.37$ \\
\hline
\end{tabular}

a Carbohydrate was equal to $100 \%$ minus the percentage of moisture, crude protein, crude lipid, and ash. ${ }^{\mathrm{b}}$ Each value is mean \pm standard deviation $(n=3)$.

\subsection{Effect of Acid Concentration and Hydrolysis Time on the Dilute Acid Pretreatment of Gracilaria sp., S. siliquosum, and U. lactuca}

Among the various pretreatments prior to enzymatic saccharification, those using dilute acids, such as sulfuric acid and hydrochloric acid, and those using alkali are considered to be effective [44,45]. As shown in Table 2, $\mathrm{HCl}$ concentrations of 0.2 and $0.4 \mathrm{~N}$ were used for the acid hydrolysis of $10 \%$ $(w / v)$ of the marine algae Gracilaria sp., S. siliquosum, and U. lactuca at $121^{\circ} \mathrm{C}$ for 20,30 , and $60 \mathrm{~min}$, individually. For the $\mathrm{HCl}$ concentrations of 0.2 and $0.4 \mathrm{~N}$, the higher the concentration of acid used, the higher the amount of reducing sugars obtained. In addition, 30 and 60 min proved to be optimal for acid hydrolysis with respect to obtaining the best reducing sugar content and yield. The former condition was adopted for the remainder of the study for dilute acid pretreatment after taking the energy cost into account. Thus, after optimum pretreatment $(0.4 \mathrm{~N} \mathrm{HCl}$ for $30 \mathrm{~min})$, the reducing sugar contents of $23.32 \pm 0.26,12.18 \pm 0.17$, and $18.89 \pm 0.39 \mathrm{~g} / \mathrm{L}$ and yields of $36.05 \pm 0.40,19.06 \pm 0.27$, and $40.06 \pm 0.89 \mathrm{~g} / \mathrm{L}$ obtained by the dilute acid hydrolysis of the marine algae Gracilaria sp., S. siliquosum, and $U$. lactuca, respectively, were achieved. Dilute acid pretreatment could minimize the release of inhibitors, such as furans and organic acids, which are normally generated under a higher concentration of acid during hydrolysis as a result of sugar degradation caused by over acid-catalyzed hydrolysis. Wu et al. [39] previously reported that $10 \%(w / v)$ of the red alga P. capillacea was hydrolyzed using $2 \%$ $(v / v)$ sulfuric acid at $121^{\circ} \mathrm{C}$, and approximately $5 \mathrm{~g} / \mathrm{L}$ of 5-hydroxymethylfurfural (5-HMF), $5 \mathrm{~g} / \mathrm{L}$ of formic acid, and $7 \mathrm{~g} / \mathrm{L}$ of levulinic acid were produced.

Table 2. The effects of various heating times and acid concentrations on the production of reducing sugar from hydrochloric acid hydrolysis of $10 \%(w / v)$ marine algae.

\begin{tabular}{ccccc}
\hline Marine Algae & $\begin{array}{c}\text { Heating Time } \\
\text { (min) }\end{array}$ & Acid Conc. (N) & $\begin{array}{c}\text { Reducing Sugar } \\
\text { Content (g/L) }\end{array}$ & $\begin{array}{c}\text { Reducing Sugar } \\
\text { Yield (\%) }\end{array}$ \\
\hline Gracilaria & \multirow{2}{*}{20} & 0.2 & $13.30 \pm 0.86^{\mathrm{d}}$ & $20.56 \pm 1.33^{\mathrm{d}}$ \\
& \multirow{2}{*}{30} & 0.4 & $21.30 \pm 0.47^{\mathrm{b}}$ & $32.93 \pm 0.73^{\mathrm{b}}$ \\
& \multirow{2}{*}{60} & 0.2 & $14.60 \pm 0.75^{\mathrm{d}}$ & $22.57 \pm 1.16^{\mathrm{d}}$ \\
& 0.4 & $23.32 \pm 0.26^{\mathrm{a}}$ & $36.05^{\mathrm{a}} \pm 0.40^{\mathrm{a}}$ \\
& 0.2 & $17.38 \pm 0.55^{\mathrm{c}}$ & $26.87 \pm 0.85^{\mathrm{c}}$ \\
& 0.4 & $24.78 \pm 0.75^{\mathrm{a}}$ & $38.31 \pm 1.16^{\mathrm{a}}$ \\
\hline
\end{tabular}


Table 2. Cont

\begin{tabular}{|c|c|c|c|c|}
\hline Marine Algae & $\begin{array}{l}\text { Heating Time } \\
\text { (min) }\end{array}$ & Acid Conc. (N) & $\begin{array}{l}\text { Reducing Sugar } \\
\text { Content }(\mathrm{g} / \mathrm{L})\end{array}$ & $\begin{array}{c}\text { Reducing Sugar } \\
\text { Yield (\%) }\end{array}$ \\
\hline \multicolumn{5}{|l|}{ S. siliquosum } \\
\hline & 20 & 0.2 & $4.19 \pm 0.09^{f}$ & $6.56 \pm 0.13^{f}$ \\
\hline & & 0.4 & $10.65 \pm 0.16^{c}$ & $16.66 \pm 0.25^{\mathrm{c}}$ \\
\hline & 30 & 0.2 & $5.48 \pm 0.48^{\mathrm{e}}$ & $8.57 \pm 0.75^{\mathrm{e}}$ \\
\hline & & 0.4 & $12.18 \pm 0.17^{b}$ & $19.06 \pm 0.27^{b}$ \\
\hline & 60 & 0.2 & $7.86 \pm 0.18^{d}$ & $12.30 \pm 0.28^{\mathrm{d}}$ \\
\hline & & 0.4 & $13.15 \pm 0.23^{a}$ & $20.57 \pm 0.36^{a}$ \\
\hline \multicolumn{5}{|l|}{ U. lactuca } \\
\hline & 20 & 0.2 & $8.83 \pm 0.12^{d}$ & $20.11 \pm 0.27^{d}$ \\
\hline & & 0.4 & $16.26 \pm 0.28^{b}$ & $37.03 \pm 0.64^{b}$ \\
\hline & 30 & 0.2 & $8.31 \pm 0.56^{d}$ & $18.93 \pm 1.28^{\mathrm{d}}$ \\
\hline & & 0.4 & $18.89 \pm 0.39^{a}$ & $40.06 \pm 0.89^{a}$ \\
\hline & 60 & 0.2 & $12.38 \pm 0.10^{\mathrm{c}}$ & $28.19 \pm 0.23^{c}$ \\
\hline & & 0.4 & $18.72 \pm 0.18^{a}$ & $42.63 \pm 0.41^{\mathrm{a}}$ \\
\hline
\end{tabular}

Each value is mean \pm standard deviation $(n=3)$; different superscript letters in the same column are significantly different $(p<0.05)$.

\subsection{The Effect of Cellulase Hydrolysis on Marine Algae Saccharification}

There have been a number of reports describing the strategy of using a combination of dilute acid/alkaline pretreatment and enzymatic hydrolysis for cellulosic biomass saccharification [43,44,46,47]. Alkaline pretreatment and enzymatic hydrolysis of wheat straw $(50 \mathrm{~g} / \mathrm{L})$ can generate a reducing sugar of $13.82 \mathrm{~g} / \mathrm{L}$ [43], and dilute acid hydrolysis followed by enzymatic hydrolysis for wood sawdust could generate glucose at $8.68 \mathrm{~g} / \mathrm{L} \mathrm{[48].} \mathrm{However,} \mathrm{few} \mathrm{studies} \mathrm{have} \mathrm{reported} \mathrm{the} \mathrm{saccharification} \mathrm{of}$ marine algae. In this study, the dilute acid hydrolysate obtained from the marine algae Gracilaria sp., S. siliquosum, and $U$. lactuca was incubated with cellulase for further saccharification. As shown in Table 3, the reducing sugar contents of the hydrolysate of the marine algae Gracilaria sp., S. siliquosum, and $U$. lactuca were increased from $21.71 \pm 0.84$ to $31.13 \pm 1.59,12.75 \pm 0.51$ to $19.51 \pm 1.68$, and $12.89 \pm 2.51$ to $18.99 \pm 1.59 \mathrm{~g} / \mathrm{L}$, respectively. This led to an increase in the reducing sugar yield of the marine algae Gracilaria sp., S. siliquosum, and $U$. lactuca from $33.56 \% \pm 1.29 \%$ to $48.12 \% \pm 2.45 \%, 19.95 \% \pm 0.76 \%$ to $30.53 \% \pm 2.60 \%$, and $27.34 \% \pm 5.75 \%$ to $40.27 \% \pm 3.63 \%$, respectively. The hydrolysate of red seaweed Gracilaria sp. was chosen for the optimization of lactic acid fermentation in further studies.

Table 3. The effects of cellulase on the production of reducing sugar from acid hydrolysis seaweeds.

\begin{tabular}{cccc}
\hline Seaweeds & Hydrolysis Steps & Reducing Sugar Content $(\mathrm{g} / \mathrm{L})$ & Reducing Sugar Yield (\%) \\
\hline Gracilaria sp. & Acid extraction & $21.71 \pm 0.84$ & $33.56 \pm 1.29$ \\
& Cellulase hydrolysis & $31.13 \pm 1.59$ & $48.12 \pm 2.45$ \\
S. siliquosum & & \\
& Acid extraction & $12.75 \pm 0.51$ & $19.95 \pm 0.76$ \\
& Cellulase hydrolysis & $19.51 \pm 1.68$ & $30.53 \pm 2.60$ \\
U. lactuca & & & \\
& Acid extraction & $12.89 \pm 2.51$ & $27.34 \pm 5.75$ \\
& Cellulase hydrolysis & $18.99 \pm 1.59$ & $40.27 \pm 3.63$ \\
\hline
\end{tabular}

Each value is mean \pm standard deviation $(n=3)$.

\subsection{The Effects of Inoculum, Agitation, and Temperature on Lactic Acid Fermentation}

It has been reported that not all of the lactic acid bacteria could ferment galactose; the dominant fermentable sugar from Gracillaria sp. hydrolysate; and some or all strains in Lactobacillus bulgaricus, 
Lactobacillus delbreckii, Lactobacillus lactis, and Lactobacillus brevis are unable to use galactose for lactic acid production [49]. Thus, the lactic acid bacteria species, such as L. acidophilus and L. plantarum, which can ferment galactose were selected, and the trials using single or combined strains of lactic acid bacteria for lactic acid fermentation of red seaweed hydrolysate were accomplished. As a result, our preliminary experiments showed that the combined use of L. acidophilus and L. plantarum had the best lactic acid production (data not shown). The effects of $1 \%, 3 \%, 6 \%, 9 \%, 12 \%, 15 \%$, and $18 \%$ $(v / v)$ inoculum of combined use of L. acidophilus and L. plantarum were tested based on cell growth, final $\mathrm{pH}$, sugar usage, and final lactic acid concentration after a $24-\mathrm{h}$ fermentation at $37^{\circ} \mathrm{C}$ (Table 4 ). The $6 \%(v / v)$ inoculum of the combined lactic acid bacteria yielded the best lactic acid concentration of $15.02 \pm 0.80 \mathrm{~g} / \mathrm{L}$; however, the difference among the combinations tested was not statistically significant. We also observed that a higher cell biomass was obtained using more inoculum of lactic acid bacteria, i.e., the highest cell biomass of $8.62 \pm 0.16 \log \mathrm{CFU} / \mathrm{mL}$ was obtained using an inoculum of $18 \%(v / v)$. Djukic-Vukovic et al. [50] indicated that 5\% (v/v) inoculum of lactic acid bacteria exhibited the best lactic acid concentration when compared with the $2 \%$ and $10 \%(v / v)$ inoculums.

Table 4. The effects of inoculum on lactic acid fermentation.

\begin{tabular}{ccccc}
\hline $\begin{array}{c}\text { Inoculum } \\
(\%, \boldsymbol{v} / \boldsymbol{v})\end{array}$ & $\begin{array}{c}\text { LAB Count } \\
(\mathbf{l o g} \text { CFU/mL) }\end{array}$ & $\begin{array}{c}\text { Reducing Sugar Content } \\
(\mathbf{g} / \mathbf{L})\end{array}$ & pH Value & $\begin{array}{c}\text { Lactic Acid Concentration } \\
(\mathrm{g} / \mathrm{L})\end{array}$ \\
\hline 1 & $8.00 \pm 0.05$ & $10.50 \pm 0.99$ & $4.20 \pm 0.15$ & $14.57 \pm 0.98^{\mathrm{a}}$ \\
3 & $8.25 \pm 0.48$ & $10.69 \pm 1.74$ & $4.14 \pm 0.18$ & $14.87 \pm 0.72^{\mathrm{a}}$ \\
6 & $8.40 \pm 0.34$ & $10.54 \pm 1.29$ & $4.11 \pm 0.22$ & $15.02^{\mathrm{a}} \pm 0.80^{\mathrm{a}}$ \\
9 & $8.49 \pm 0.20$ & $12.10 \pm 1.61$ & $4.20 \pm 0.19$ & $14.54 \pm 0.43^{\mathrm{a}}$ \\
12 & $8.51 \pm 0.19$ & $13.80 \pm 2.34$ & $4.37 \pm 0.41$ & $13.95 \pm 1.29^{\mathrm{a}}$ \\
15 & $8.59 \pm 0.12$ & $14.52 \pm 2.50$ & $4.56 \pm 0.44$ & $13.24 \pm 1.13^{\mathrm{a}}$ \\
18 & $8.62 \pm 0.16$ & $13.31 \pm 1.29$ & $4.34 \pm 0.26$ & $13.71 \pm 1.62^{\mathrm{a}}$ \\
\hline
\end{tabular}

Each value is mean \pm standard deviation $(n=3)$; different superscript letters in the same column are significantly different $(p<0.05)$.

The effects of $0,50,100$, and $150 \mathrm{rpm}$ of lactic acid fermentation were tested based on cell growth, final $\mathrm{pH}$, sugar usage, and the final lactic acid concentration after a $24-\mathrm{h}$ fermentation at $37^{\circ} \mathrm{C}$ (Table 5). The 0 -rpm condition exhibited the best lactic acid concentration of $15.08 \pm 0.25 \mathrm{~g} / \mathrm{L}$, indicating that the anaerobic environment was suitable for lactic acid fermentation. Lactobacilli are rod-shaped, gram-positive, and microaerophilic to strictly anaerobic microorganisms [51].

Table 5. The effects of agitation on lactic acid fermentation.

\begin{tabular}{ccccc}
\hline $\begin{array}{c}\text { Shaking } \\
\text { Incubation (rpm) }\end{array}$ & $\begin{array}{c}\text { LAB Count (log } \\
\text { CFU/mL) }\end{array}$ & $\begin{array}{c}\text { Reducing Sugar } \\
\text { Content }(\mathrm{g} / \mathbf{L})\end{array}$ & pH Value & $\begin{array}{c}\text { Lactic Acid } \\
\text { Concentration }(\mathbf{g} / \mathrm{L})\end{array}$ \\
\hline 0 & $8.94 \pm 0.11$ & $12.75 \pm 0.16$ & $4.26 \pm 0.02$ & $15.08 \pm 0.25^{\mathrm{a}}$ \\
50 & $8.88 \pm 0.13$ & $12.75 \pm 0.25$ & $4.35 \pm 0.03$ & $14.63 \pm 0.10^{\mathrm{b}}$ \\
100 & $8.77 \pm 0.10$ & $15.01 \pm 0.38$ & $4.77 \pm 0.05$ & $12.48 \pm 0.04^{\mathrm{c}}$ \\
150 & $8.79 \pm 0.14$ & $14.77 \pm 0.30$ & $4.96 \pm 0.01$ & $12.62 \pm 0.19^{\mathrm{c}}$ \\
\hline
\end{tabular}

Each value is mean \pm standard deviation $(n=3)$; different superscript letters in the same column are significantly different $(p<0.05)$.

The optimum temperature conditions for cell growth and metabolism are sometimes strain specific. The effects of temperature on lactic acid fermentation were tested based on cell growth, final $\mathrm{pH}$, sugar usage, and the final lactic acid concentration after a 24 -h fermentation at 26,30 , and $37^{\circ} \mathrm{C}$ (Table 6). Our data indicated that 30 and $37^{\circ} \mathrm{C}$ were optimum for lactic acid fermentation. Lactobacilli have been reported to grow well at 30,34 , and $37^{\circ} \mathrm{C}$ but very slowly at $40^{\circ} \mathrm{C}$ [52]. 
Table 6. The effects of temperature on lactic acid fermentation.

\begin{tabular}{ccccc}
\hline $\begin{array}{c}\text { Fermentation } \\
\text { Temperature }\left({ }^{\circ} \mathbf{C}\right)\end{array}$ & $\begin{array}{c}\text { LAB Count }(\mathbf{l o g} \\
\text { CFU/mL) }\end{array}$ & $\begin{array}{c}\text { Reducing Sugar } \\
\text { Content }(\mathrm{g} / \mathrm{L})\end{array}$ & pH Value & $\begin{array}{c}\text { Lactic Acid } \\
\text { Concentration }(\mathrm{g} / \mathrm{L})\end{array}$ \\
\hline 26 & $8.42 \pm 0.23$ & $13.73 \pm 0.12$ & $4.99 \pm 0.02$ & $13.39 \pm 0.19^{\mathrm{b}}$ \\
30 & $9.23 \pm 0.11$ & $12.55 \pm 0.04$ & $4.43 \pm 0.03$ & $14.21 \pm 0.16^{\mathrm{a}}$ \\
37 & $9.03 \pm 0.05$ & $12.50 \pm 0.37$ & $4.41 \pm 0.07$ & $14.24 \pm 0.14^{\mathrm{a}}$ \\
\hline
\end{tabular}

Each value is mean \pm standard deviation $(\mathrm{n}=3)$; different superscript letters in the same column are significantly different $(p<0.05)$.

\subsection{Optimum Conditions for Lactic Acid Fermentation}

Gracilaria sp. hydrolysate was added with $6 \%(v / v)$ of inoculum of lactic acid bacteria for lactic acid fermentation at $30^{\circ} \mathrm{C}, 0 \mathrm{rpm}$ for $72 \mathrm{~h}$. Fermentation was monitored for the production of lactic acid, reducing sugar usage, cell count, and $\mathrm{pH}$. As shown in Figure 1, lactic acid rapidly accumulated within $24 \mathrm{~h}$ and reached a plateau within $36 \mathrm{~h}$, which could be due to the rapid decrease in $\mathrm{pH}$. The lactic acid production had another increase by $15 \%$ when the $\mathrm{pH}$ was adjusted from 4.4 to 5.6 by adding $\mathrm{CaCO}_{3}$ at $36 \mathrm{~h}$, and the highest lactic acid concentration of $19.32 \mathrm{~g} / \mathrm{L}$ was attained at $72 \mathrm{~h}$. The conversion yield from seaweeds to lactic acid is calculated to be $0.19 \mathrm{~g} / \mathrm{g}$. An initial concentration of $29.85 \mathrm{~g} / \mathrm{L}$ of reducing sugars in the Gracilaria sp. hydrolysate was used in the lactic acid fermentation, and two-third of the reducing sugars were consumed in $72 \mathrm{~h}$. The residual sugar in fermentation could be the non-fermentable sugar 3,6-anhydrogalactose. Gracilaria sp. comprise polysaccharide chains made of repeating alternative units of fermentable simple sugar galactose and non-fermentable sugar 3,6-anhydrogalactose [53]; however, the latter cannot be used by lactic acid bacteria. To date, lactic acid has been reported to be produced by starchy and lignocellulosic biomass sources, such as corn and sugar cane waste $[18,19]$, but very few reports exist on the production of lactic acid by algae. Nguyen et al. [54] used L. paracasei LA104 for simultaneous saccharification and co-fermentation for lactic acid production using the enzymatic hydrolysates of the freshwater microalga Hydrodictyon recticulum, which contains a high amount of polysaccharides, mainly glucose and mannose. This is the first study that reports the lactic acid fermentation of seaweeds, indicating its potential as biomass for lactic acid production.

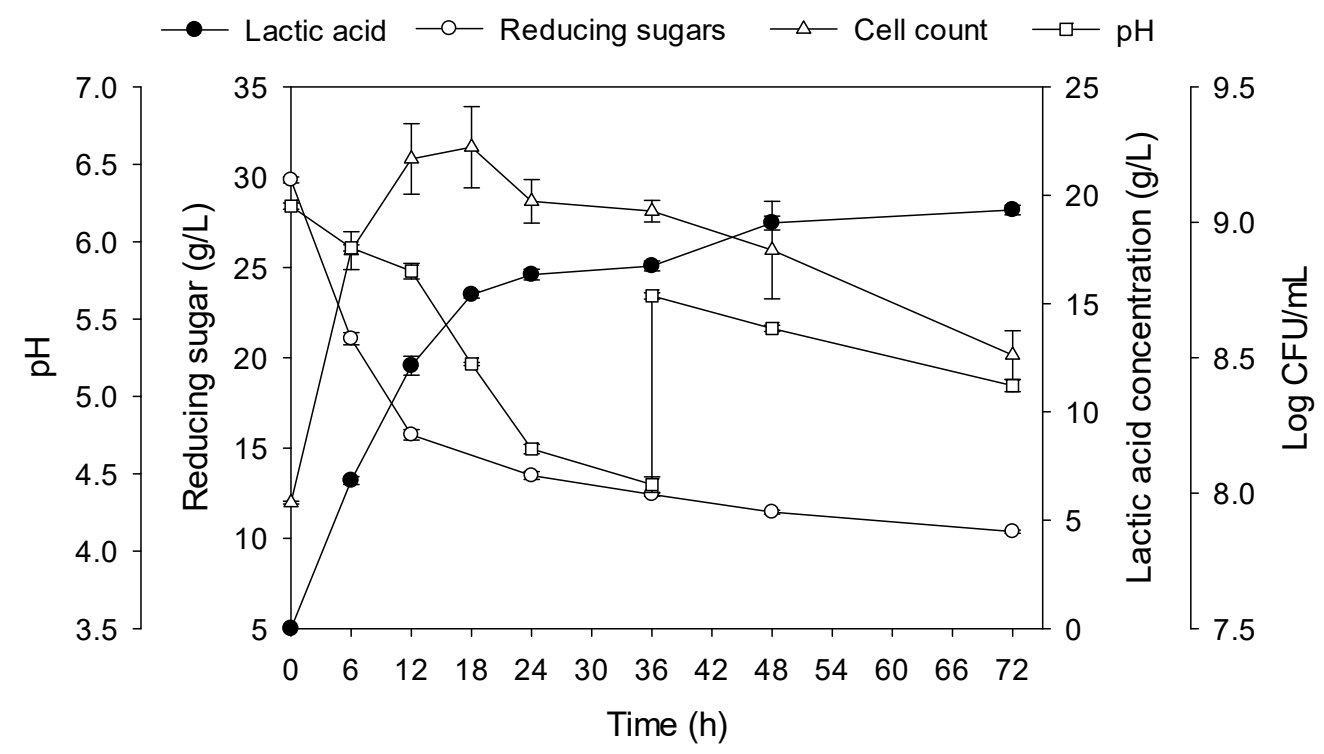

Figure 1. Lactic acid fermentation of Gracilaria sp. hydrolysate by lactic acid bacteria strains BCRC 10695 and $12327.3 \%(v / v)$ of the Lb. acidophilus (BCRC 10695) and Lb. plantarum (BCRC 12327) were inoculated and the fermentation were accomplished at $30^{\circ} \mathrm{C}$ for $72 \mathrm{~h}$. Each value is mean \pm standard deviation $(n=3)$. 


\section{Materials and Methods}

\subsection{Source of Marine Algae and Lactic Acid Bacteria}

Dried Gracilaria sp. was purchase from Yunlin country, Taiwan, and dried Sargassum siliquosum, and Ulva lactuca were purchased from a local market in Hoping Island, Keelung, Taiwan. The seaweed was ground, sieved ( $1 \mathrm{~mm}$ pore size), and stored at $-20{ }^{\circ} \mathrm{C}$ before use. The proximate composition, including the moisture, crude protein, crude lipid, crude fiber, and ash of the marine algae, were analyzed according to Association of Official Analytical Chemists (AOAC) official methods of analysis [55]. The lactic acid bacteria strains Lactobacillus (Lb.) acidophilus BCRC 10695 and Lb. plantarum BCRC 12327 used in this study were purchased from Bioresources Collection and Research Center (BCRC) in Hsinchu.

\subsection{Preparation of the Marine Algae Hydrolysate and Lactic Acid Fermentation}

The experiments were accomplished according to a previous report [56] with some modifications. In this study, $10 \%(w / v)$ of marine algae were treated with $0.2 \mathrm{~N}$ and $0.4 \mathrm{~N} \mathrm{HCl}$ for 20, 30, and $60 \mathrm{~min}$ for pretreatment. An optimum pretreatment condition was selected for dilute $\mathrm{HCl}$ hydrolysis. The $\mathrm{pH}$ of the acid hydrolysates was adjusted to $\mathrm{pH} 4.5$ after pretreatment and incubated with $7.6 \mathrm{U} / \mathrm{mL}$ cellulase (Amano Enzyme, Elgin, IL, USA) at $37^{\circ} \mathrm{C}$ for $48 \mathrm{~h}$ for enzymatic saccharification. $3 \%$ ( $v / v$ ) inoculum of BCRC 10695 and 12327 was inoculated into the hydrolysate of Gracilaria sp. for lactic acid fermentation at $30{ }^{\circ} \mathrm{C}$ for $24 \mathrm{~h} \mathrm{[57].}$

\subsection{Reducing Sugars Quantification Using DNS (3,5-Dinitrosalicylic Acid) Assay}

The experiments were accomplished according to Miller [58], and the standard curve was accomplished by using simple sugar galactose (Formedium, Hungstanton, Norfolk, UK). In brief, the sample was centrifuged at $10,000 \times g$ at room temperature for $5 \mathrm{~min}$. The supernatant was collected and mixed with an equal volume of DNS (3,5-dinitrosalicylic acid) reagent (Sigma-Aldrich, St. Louis, MO, USA). The mixture was heated at $100{ }^{\circ} \mathrm{C}$ for $10 \mathrm{~min}$, and cooled prior to being mixed with an equal volume of deionized water. The mixture was measured at an absorbance at $546 \mathrm{~nm}$, and the reducing sugar contents were calculated. The seaweed hydrolysate analyzed for reducing sugar contents, and the reducing sugar yields were calculated according to a previous report [59] as follows:

Reducing sugar yield = reducing sugar content/weight of dried algae powder/ratio of carbohydrate $\times 100 \%$.

\subsection{Analysis of Lactic Acid Using HPLC}

The lactic acid (g) was analyzed using an Asahipak GS-320 HQ (7.5 × $300 \mathrm{~mm})$ (Showa Denko America, Inc., New York, NY, USA), along with a refractive index detector with a filtered distilled water eluent at a flow rate of $0.4 \mathrm{~mL} / \mathrm{min}$ at $40^{\circ} \mathrm{C}$. All the tested samples were filtered through a $0.22-\mu \mathrm{m}$ membrane filter prior to the HPLC analysis [60].

\subsection{Effect of Inoculum, Agitation, and Temperature on Lactic Acid Fermentation}

For optimizations of cell inoculum, 1\%, 3\%,6\%, 9\%, 12\%, 15\%, and 18\% (v/v) of inoculum at the density of $1 \times 10^{9} \mathrm{CFU} / \mathrm{mL}$ of lactic acid bacteria (BCRC 10695 and 12327, mixing ratio = 1:1) was inoculated into Gracilaria sp. hydrolysate containing 0.5\% (w/v) yeast extract (Formedium, Hungstanton, Norfolk, UK), and the fermentation mixture was incubated at $37{ }^{\circ} \mathrm{C}$ without shaking for $72 \mathrm{~h}$. For optimizations of the agitation rate, $6 \%(v / v)$ of inoculum of lactic acid bacteria (BCRC 10695 and 12327) was inoculated into Gracilaria sp. hydrolysate containing $0.5 \%(w / v)$ yeast extract, and the fermentation mixture was incubated at $37^{\circ} \mathrm{C}$ with a shaking rate of $0,100,150$, or $200 \mathrm{rpm}$ for $72 \mathrm{~h}$. For optimizations of the fermentation temperature, $6 \%(v / v)$ of inoculum of lactic acid bacteria (BCRC 10695 and 12327) was inoculated into Gracilaria sp. hydrolysate containing $0.5 \%$ ( $w / v)$ yeast extract, 
and the fermentation mixture was incubated at 25,30 , and $37^{\circ} \mathrm{C}$ for $72 \mathrm{~h}$. The samples were collected at the end of fermentation for analyses of the cells counts, reducing sugar contents, $\mathrm{pH}$, and lactic acid concentration [61].

\subsection{Statistical Analysis}

Data were analyzed statistically using SPSS Version 12.0 (SPSS Inc., Chicago, IL, USA). One-way analysis of variance (ANOVA) was used to determine statistical differences between sample means, with the level of significance set at $p<0.05$. Multiple comparisons of means were done by Duncan's test. All data are expressed as mean \pm SD.

\section{Conclusions}

In this study, we evaluated red, brown, and green seaweeds for lactic acid fermentation. The optimum acid/enzyme hydrolysis condition for the saccharification of the seaweeds was determined, and the lactic acid fermentation parameters of the red seaweed hydrolysate were optimized. Our study identifies a practical approach to use seaweeds as a carbon source for lactic acid fermentation.

Author Contributions: H.-T.V.L. participated in the research design, and constructed the manuscript. M.-Y.H., T.-Y.K., W.-J.L., and H.-J.L. participated in the experiments, data analyses and statistics. C.-L.P. participated in the research design and revision of manuscript content. All authors have read and agree to the published version of the manuscript.

Funding: This research received no external funding.

Acknowledgments: This work was supported by grants from the Ministry of Science and Technology, R. O. C. (MOST 105-2221-E-019-075 and MOST 106-2221-E-019-065), and by the Center of Excellence for the Oceans, National Taiwan Ocean University from The Featured Areas Research Center Program within the framework of the Higher Education Sprout Project by the Ministry of Education (MOE) in Taiwan (NTOU-RD-AA-2019-1-02011-2).

Conflicts of Interest: The authors declare no conflicts of interest.

\section{References}

1. John, R.P.; Anisha, G.S.; Nampoothiri, K.M.; Pandey, A. Direct lactic acid fermentation: Focus on simultaneous saccharification and lactic acid production. Biotechnol. Adv. 2009, 27, 145-152. [CrossRef] [PubMed]

2. Wee, Y.J.; Kim, J.N.; Ryu, H.W. Biotechnological production of lactic acid and its recent applications. Food Technol. Biotechnol. 2006, 44, 163-172.

3. Mora-Villalobos, J.A.; Montero-Zamora, J.; Barboza, N.; Rojas-Garbanzo, C.; Usaga, J.; Redondo-Solano, M.; Schroedter, L.; Olszewska-Widdrat, A.; López-Gómez, J.P. Multi-product lactic acid bacteria fermentations: A review. Fermentation 2020, 6, 23. [CrossRef]

4. Liaud, N.; Rosso, M.N.; Fabre, N.; Crapart, S.; Herpoel-Gimbert, I.; Sigoillot, J.C.; Raouche, S.; Levasseur, A. L-lactic acid production by Aspergillus brasiliensis overexpressing the heterologous ldha gene from Rhizopus oryzae. Microb. Cell. Fact. 2015, 14, 1-9. [CrossRef] [PubMed]

5. Datta, R.; Tsai, S.P.; Bonsignore, P.; Moon, S.H.; Frank, J.R. Technological and economic-potential of poly (lactic acid) and lactic-acid derivatives. FEMS Microbiol. Rev. 1995, 16, 221-231. [CrossRef]

6. Maas, R.H.; Bakker, R.R.; Eggink, G.; Weusthuis, R.A. Lactic acid production from xylose by the fungus Rhizopus oryzae. Appl. Microbiol. Biotechnol. 2006, 72, 861-868. [CrossRef] [PubMed]

7. Maas, R.H.; Springer, J.; Eggink, G.; Weusthuis, R.A. Xylose metabolism in the fungus Rhizopus oryzae: Effect of growth and respiration on L(+)-lactic acid production. J. Ind. Microbiol. Biotechnol. 2008, 35, 569-578. [CrossRef]

8. Yamane, T.; Tanaka, R. Mass production of spores of lactic acid-producing Rhizopus oryzae NBRC 5384 on agar plate. Biotechnol. Prog. 2013, 29, 876-881. [CrossRef]

9. Ilmen, M.; Koivuranta, K.; Ruohonen, L.; Suominen, P.; Penttila, M. Efficient production of L-lactic acid from xylose by Pichia stipitis. Appl. Environ. Microbiol. 2007, 73, 117-123. [CrossRef]

10. Sun, W.; Liu, J.; Xu, H.; Li, W.; Zhang, J. L-lactic acid fermentation by Enterococcus faecium: A new isolate from bovine rumen. Biotechnol. Lett. 2015, 37, 1379-1383. [CrossRef] 
11. Zhang, Y.; Vadlani, P.V. Lactic acid production from biomass-derived sugars via co-fermentation of Lactobacillus brevis and Lactobacillus plantarum. J. Biosci. Bioeng. 2015, 119, 694-699. [CrossRef]

12. Abdel-Rahman, M.A.; Tashiro, Y.; Sonomoto, K. Recent advances in lactic acid production by microbial fermentation processes. Biotechnol. Adv. 2013, 31, 877-902. [CrossRef]

13. de Lima, C.J.B.; Coelho, L.F.; Contiero, J. The use of response surface methodology in optimization of lactic acid production: Focus on medium supplementation, temperature and $\mathrm{pH}$ control. Food Technol. Biotechnol. 2010, 48, 175-181.

14. Nuzzo, G.; Landi, S.; Esercizio, N.; Manzo, E.; Fontana, A.; d'Ippolito, G. Capnophilic lactic fermentation from Thermotoga neapolitana: A resourceful pathway to obtain almost enantiopure l-lactic acid. Fermentation 2019, 5, 34. [CrossRef]

15. Ishida, N.; Saitoh, S.; Tokuhiro, K.; Nagamori, E.; Matsuyama, T.; Kitamoto, K.; Takahashi, H. Efficient production of L-lactic acid by metabolically engineered Saccharomyces cerevisiae with a genome-integrated L-lactate dehydrogenase gene. Appl. Environ. Microbiol. 2005, 71, 1964-1970. [CrossRef]

16. Wakai, S.; Yoshie, T.; Asai-Nakashima, N.; Yamada, R.; Ogino, C.; Tsutsumi, H.; Hata, Y.; Kondo, A. L-lactic acid production from starch by simultaneous saccharification and fermentation in a genetically engineered Aspergillus oryzae pure culture. Bioresour. Technol. 2014, 173, 376-383. [CrossRef]

17. Koivuranta, K.T.; Ilmen, M.; Wiebe, M.G.; Ruohonen, L.; Suominen, P.; Penttila, M. L-lactic acid production from D-xylose with Candida sonorensis expressing a heterologous lactate dehydrogenase encoding gene. Microb. Cell. Fact. 2014, 13, 107. [CrossRef]

18. Adsul, M.G.; Varma, A.J.; Gokhale, D.V. Lactic acid production from waste sugarcane bagasse derived cellulose. Green Chem. 2007, 9, 58-62. [CrossRef]

19. Okano, K.; Zhang, Q.; Shinkawa, S.; Yoshida, S.; Tanaka, T.; Fukuda, H.; Kondo, A. Efficient production of optically pure D-lactic acid from raw corn starch by using a genetically modified L-lactate dehydrogenase gene-deficient and alpha-amylase-secreting Lactobacillus plantarum strain. Appl. Environ. Microbiol. 2009, 75, 462-467. [CrossRef]

20. Cheng, P.; Mueller, R.E.; Jaeger, S.; Bajpai, R.; Lannotti, E.L. Lactic acid production from enzyme-thinned corn starch using Lactobacillus amylovorus. J. Ind. Microbiol. 1991, 7, 27-34. [CrossRef]

21. Yin, P.M.; Nishina, N.; Kosakai, Y.; Yahiro, K.; Park, Y.; Okabe, M. Enhanced production of L(+)-lactic acid from corn starch in a culture of Rhizopus oryzae using an air-lift bioreactor. J. Ferment. Bioeng. 1997, 84, 249-253. [CrossRef]

22. Fukushima, K.; Sogo, K.; Miura, S.; Kimura, Y. Production of D-lactic acid by bacterial fermentation of rice starch. Macromol. Biosci. 2004, 4, 1021-1027. [CrossRef]

23. Huang, L.P.; Jin, B.; Lant, P.; Zhou, J.T. Simultaneous saccharification and fermentation of potato starch wastewater to lactic acid by Rhizopus oryzae and Rhizopus arrhizus. Biochem. Eng. J. 2005, 23, $265-276$. [CrossRef]

24. Anuradha, R.; Suresh, A.K.; Venkatesh, K.V. Simultaneous saccharification and fermentation of starch to lactic acid. Process Biochem. 1999, 35, 367-375. [CrossRef]

25. Olszewska-Widdrat, A.; Alexandri, M.; López-Gómez, J.P.; Schneider, R.; Mandl, M.; Venus, J. Production and purification of 1-lactic acid in lab and pilot scales using sweet sorghum juice. Fermentation 2019, 5, 36. [CrossRef]

26. Zhao, K.; Qiao, Q.G.; Chu, D.Q.; Gu, H.Q.; Dao, T.H.; Zhang, J.; Bao, J. Simultaneous saccharification and high titer lactic acid fermentation of corn stover using a newly isolated lactic acid bacterium Pediococcus acidilactici DQ2. Bioresour. Technol. 2013, 135, 481-489. [CrossRef]

27. Gullon, B.; Yanez, R.; Alonso, J.L.; Parajo, J.C. L-lactic acid. production from apple pomace by sequential hydrolysis and fermentation. Bioresour. Technol. 2008, 99, 308-319. [CrossRef]

28. Zhang, Y.M.; Chen, X.R.; Qi, B.K.; Luo, J.Q.; Shen, F.; Su, Y.; Khan, R.; Wan, Y.H. Improving lactic acid productivity from wheat straw hydrolysates by membrane integrated repeated batch fermentation under non-sterilized conditions. Bioresour. Technol. 2014, 163, 160-166. [CrossRef]

29. Maas, R.H.W.; Bakker, R.R.; Jansen, M.L.A.; Visser, D.; De Jong, E.; Eggink, G.; Weusthuis, R.A. Lactic acid production from lime-treated wheat straw by Bacillus coagulans: Neutralization of acid by fed-batch addition of alkaline substrate. Appl. Microbiol. Biotechnol. 2008, 78,751-758. [CrossRef]

30. Wee, Y.J.; Yun, J.S.; Park, D.H.; Ryu, H.W. Biotechnological production of L(+)-lactic acid from wood hydrolyzate by batch fermentation of Enterococcus faecalis. Biotechnol. Lett. 2004, 26, 71-74. [CrossRef] 
31. Dominguez-Faus, R.; Powers, S.E.; Burken, J.G.; Alvarez, P.J. The water footprint of biofuels: A drink or drive issue? Environ. Sci. Technol. 2009, 43, 3005-3010. [CrossRef]

32. Sebayang, A.H.; Masjuki, H.H.; Ong, H.C.; Dharma, S.; Silitonga, A.S.; Mahlia, T.M.I.; Aditiya, H.B. A perspective on bioethanol production from biomass as alternative fuel for spark ignition engine. RSC Adv. 2016, 6, 14964-14992. [CrossRef]

33. Jung, K.A.; Lim, S.R.; Kim, Y.; Park, J.M. Potentials of macroalgae as feedstocks for biorefinery. Bioresour. Technol. 2013, 135, 182-190. [CrossRef]

34. Enriquez, S.; Duarte, C.M.; SandJensen, K.; Nielsen, S.L. Broad-scale comparison of photosynthetic rates across phototrophic organisms. Oecologia 1996, 108, 197-206. [CrossRef]

35. Sharif Hossain, A.B.M.; Salleh, A. Biodiesel fuel production from algae as renewable energy. Am. J. Biochem. Biotechnol. 2008, 4, 250-254.

36. Kim, S.K.; Chojnacka, K. (Eds.) Marine Algae Extracts: Processes, Products, and Applications; Wiley-VCH: Weinheim, Germany, 2015.

37. Uchida, M.; Miyoshi, T. Algal fermentation-the seed for a new fermentation industry of foods and related products. JARQ Jpn. Agric. Res. Q. 2013, 47, 53-63. [CrossRef]

38. Hwang, H.J.; Lee, S.Y.; Kim, S.M.; Lee, S.B. Fermentation of seaweed sugars by Lactobacillus species and the potential of seaweed as a biomass feedstock. Biotechnol. Bioprocess Eng. 2011, 16, 1231-1239. [CrossRef]

39. Wu, C.H.; Chien, W.C.; Chou, H.K.; Yang, J.; Lin, H.T.V. Sulfuric acid hydrolysis and detoxification of red alga Pterocladiella capillacea for bioethanol fermentation with thermotolerant yeast Kluyveromyces marxianus. J. Microbiol. Biotechnol. 2014, 24, 1245-1253. [CrossRef] [PubMed]

40. Park, J.H.; Hong, J.Y.; Jang, H.C.; Oh, S.G.; Kim, S.H.; Yoon, J.J.; Kim, Y.J. Use of Gelidium amansii as a promising resource for bioethanol: A practical approach for continuous dilute-acid hydrolysis and fermentation. Bioresour. Technol. 2012, 108, 83-88. [CrossRef]

41. Ortiz, J.; Romero, N.; Robert, P.; Araya, J.; Lopez-Hernandez, J.; Bozzo, C.; Navarrete, E.; Osorio, A.; Rios, A. Dietary fiber, amino acid, fatty acid and tocopherol contents of the edible seaweeds Ulva lactuca and Durvillaea antarctica. Food Chem. 2006, 99, 98-104. [CrossRef]

42. Jang, J.S.; Cho, Y.; Jeong, G.T.; Kim, S.K. Optimization of saccharification and ethanol production by simultaneous saccharification and fermentation (SSF) from seaweed, Saccharina japonica. Bioprocess Biosyst. Eng. 2012, 35, 11-18. [CrossRef] [PubMed]

43. Wang, J.; Wang, Q.H.; Xu, Z.; Zhang, W.Y.; Xiang, J. Effect of fermentation conditions on 1-lactic acid production from soybean straw hydrolysate. J. Microbiol. Biotechnol. 2015, 25, 26-32. [CrossRef] [PubMed]

44. Saha, B.C.; Iten, L.B.; Cotta, M.A.; Wu, Y.V. Dilute acid pretreatment, enzymatic saccharification and fermentation of wheat straw to ethanol. Process Biochem. 2005, 40, 3693-3700. [CrossRef]

45. Meinita, M.D.N.; Hong, Y.K.; Jeong, G.T. Comparison of sulfuric and hydrochloric acids as catalysts in hydrolysis of Kappaphycus alvarezii (cottonii). Bioprocess Biosyst. Eng. 2012, 35, 123-128. [CrossRef] [PubMed]

46. Saha, B.C.; Iten, L.B.; Cotta, M.A.; Wu, Y.V. Dilute acid pretreatment, enzymatic saccharification, and fermentation of rice hulls to ethanol. Biotechnol. Prog. 2005, 21, 816-822. [CrossRef] [PubMed]

47. Qureshi, N.; Saha, B.C.; Hector, R.E.; Cotta, M.A. Removal of fermentation inhibitors from alkaline peroxide pretreated and enzymatically hydrolyzed wheat straw: Production of butanol from hydrolysate using Clostridium beijerinckii in batch reactors. Biomass Bioenerg. 2008, 32, 1353-1358. [CrossRef]

48. Nancib, A.; Diboune, N.; Nancib, N.; Boudrant, J. Statistical optimization of dilute acid hydrolysis of wood sawdust for lactic acid production. J. Appl. Biotech. Bioeng. 2017, 4, 502-509. [CrossRef]

49. Holzapfel, W.H.; Wood, B.J.B. Lactic Acid Bacteria: Biodiversity and Taxonomy; Wiley Blackwell: Chichester, West Sussex, UK, 2014. [CrossRef]

50. Djukic-Vukovic, A.P.; Mojovic, L.V.; Vukasinovic-Sekulic, M.S.; Rakin, M.B.; Nikolic, S.B.; Pejin, J.D.; Bulatovic, M.L. Effect of different fermentation parameters on L-lactic acid production from liquid distillery stillage. Food Chem. 2012, 134, 1038-1043. [CrossRef]

51. Salminen, S. Lactic Acid Bacteria: Microbiological and Functional Aspects, 4th ed.; CRC Press: Boca Raton, FL, USA; Taylor \& Francis: Abingdon, UK, 2012; p. 777.

52. Wardani, S.K.; Cahyanto, M.N.; Rahayu, E.S.; Utami, T. The effect of inoculum size and incubation temperature on cell growth, acidproduction and curd formation during milk fermentation by Lactobacillus plantarum Dad 13. Int. Food Res. J. 2017, 24, 921-926. 
53. Quemener, B.; Lahaye, M. Comparative analysis of sulfated galactans from red algae by reductive hydrolysis and mild methanolysis coupled to two different HPLC techniques. J. Appl. Phycol. 1998, 10, 75-81. [CrossRef]

54. Nguyen, C.M.; Kim, J.S.; Hwang, H.J.; Park, M.S.; Choi, G.J.; Choi, Y.H.; Jang, K.S.; Kim, J.C. Production of 1-lactic acid from a green microalga, Hydrodictyon reticulum, by Lactobacillus paracasei LA104 isolated from the traditional Korean food, makgeolli. Bioresour. Technol. 2012, 110, 552-559. [CrossRef] [PubMed]

55. Association of Official Analytical Chemists (AOAC). Official Methods of Analysis of the AOAC, 15th ed.; Association of Official Analytical Chemists: Washington, DC, USA, 1998.

56. Harrigan, W.F.; McCance, M.E. Laboratory Methods in Food and Dairy Microbiology, Rev. ed.; Academic Press: Cambridge, MA, USA, 1976; p. 452.

57. Trontel, A.; Batusic, A.; Gusic, I.; Slavica, A.; Santek, B.; Novak, S. Production of D- and L-Lactic Acid by Mono- and mixed cultures of Lactobacillus sp. Food Technol. Biotechnol. 2011, 49, 75-82.

58. Miller, G.L. Use of dinitrosalicylic acid reagent for reagent for determination of reducing sugars. Anal. Chem. 1959, 31, 426-428. [CrossRef]

59. Jang, S.; Shirai, Y.; Uchida, M.; Wakisaka, M. Production of L(+)-lactic acid from mixed acid and alkali hydrolysate of brown seaweed. Food Sci. Technol. Res. 2011, 17, 155-160. [CrossRef]

60. Gardner, N.J.; Savard, T.; Obermeier, P.; Caldwell, G.; Champagne, C.P. Selection and characterization of mixed starter cultures for lactic acid fermentation of carrot, cabbage, beet and onion vegetable mixtures. Int. J. Food Microbiol. 2001, 64, 261-275. [CrossRef]

61. Martinez, F.A.C.; Balciunas, E.M.; Salgado, J.M.; Gonzalez, J.M.D.; Converti, A.; Oliveira, R.P.D. Lactic acid properties, applications and production: A review. Trends Food Sci. Tech. 2013, 30, 70-83. [CrossRef]

(C) 2020 by the authors. Licensee MDPI, Basel, Switzerland. This article is an open access article distributed under the terms and conditions of the Creative Commons Attribution (CC BY) license (http://creativecommons.org/licenses/by/4.0/). 